REVIEW ARTICLE

\title{
Medicolegal Aspects of Hurt, Injury and Wound
}

\author{
*A Barek ${ }^{1}$, SMT Haque ${ }^{2}$ \\ $1 *$ Prof. Dr. Abdul Barek, Professor \& Head, Department of Forensic Medicine \\ Anwer Khan Modern Medical College, Dhanmondi, Dhaka \\ ${ }^{2}$ Dr. Syed Mohammad Tanjilul Haque, Assistant Professor. Department of Forensic Medicine \\ Anwer Khan Modern Medical College, Dhanmondi, Dhaka
}

*Corresponding author

\begin{abstract}
Legal term hurt means bodily pain, injury or wound and disease or infirmity caused to any person. Abrasion, bruise, laceration, fracture, dislocation, incised wound, stab wound, puncture, penetrating wound, firearm wound, bomb blast wound, burn, scald are common types of injury or hurt. Different types of weapons or means used to cause hurts are blunt, sharp and pointed weapons, firearms, bombs, heat, electricity and corrosives. For legal purposes, hurts are grouped as grievous hurt and simple hurt. There are eight categories of grievous hurt. In reporting hurt cases, the clinical state of the victim with full description of the wounds are noted and an opinion regarding their legal state i.e. whether grievous or simple, age of the injury, type of the weapon or means causing the injury, whether inflicted by others or self inflicted etc. is given. These help the court to give its judgment. There are enacted laws describing section, numbers, types of crime and their punishments.
\end{abstract}

Key words: Hurt, Injury, Weapons and Means, Medicolegal report, imprisonment and fine.

\section{Introduction}

Medical practitioners very frequently need to examine, treat victims and issue medicolegal reports in pursuit of their profession dealing with wounded persons. Law enforcing officers may send the wounded victims for routine treatment and necessarily for medicolegal reports of the cases. Occasionally the victims from their own selves request the attending medical practitioners to issue medical certificates and reports which will be needed to start a legal action against the accused persons. This is why the medical practitioners have to use their medical knowledge and skill regarding hurts or injuries, different causative weapons or means for making very useful medicolegal reports and on a later date to act as competent expert witness in the courts of law.

\section{Discussion}

The term hurt ${ }^{1}$, injury ${ }^{2}$ and wound ${ }^{3}$ have almost the same meaning and some differences as well. They usually mean any damage to any part of the body or bodily harm caused by application of violence. Injury also includes any harm to the mind, reputation and property, and hurt includes bodily pain, disease or infirmity. Clinically a wound is produced when there is breach of anatomical continuity of the skin or mucous membrane with or without damage of the underlying tissues. Forensically it is wound when there is damage of any tissue or organ irrespective of breach of continuity of the skin or mucous membrane.

Production of wound ${ }^{4,11}$ : A wound is produced when the intensity of the applied force to the body exceeds the capability of the tissue to adapt or resist the force. The capability of the tissue to adapt or resist the force depends on mass, velocity, exact area of the weapon pressing the body, structure of the tissue, mode of application of the applied force like compression, traction, torsion, tangent and leverage of the stress. Type of damage of the tissue depends on the degree of transfer of the kinetic energy from the relative movement of the weapon and/or the body. 
Medicolegal Aspects of Hurt, Injury and Wound

Type of wounds ${ }^{5,9}$ : Wounds are typed on the basis of their appearance and the method of causation. Abrasion- It is the damage occurring in the epidermis; some dermal papillae may also be damaged. It is caused by rough hard blunt objects or surfaces or by drawing the tip of the pointed objects against the skin or mucous membrane. Most abrasions are caused by rubbing effect and others are caused by vertical pressure. Pattern of the impacting object may be retained at the abraded area. Bruise- It is the extravascular collection of blood in the tissue, viz, dermis of the skin, subcutaneous tissue and other deeper tissues due to rupture of blood vessels caused by application of blunt force with overlying tissue remaining intact so that blood cannot escape outside. When the lesion is visible from outside it is called bruise and if not visible from outside it is called contusion. Bruises may be of different sizes, viz, petechial haemorrhage of pin head size, purpura of size 2 to $5 \mathrm{~mm}$, echymosis of more than $5 \mathrm{~mm}$, haematoma causing local swelling. Laceration- it is the tearing or splitting of the skin, mucous membrane and surfaces of any internal organs caused by application of blunt force. Blood escapes from the wound to the exterior or any body cavity. Fracture- It is the breach of continuity of bone or tooth caused by application of blunt force. Clinical features and X-ray findings are considered to diagnose this type of lesion. In dislocation of joint the bone ends get displaced completely from their normal anatomical positions with damage to the adjacent tissues. Incised wound- It is caused by the sharp edge of the weapon applied to the skin perpendicularly or obliquely making regular clean edges of the wound. It is called a slash wound when the length of the wound is greater than its depth.

It is stab wound ${ }^{\mathbf{6}, 12}$ when its depth is greater than its length and usually caused by pointed knife or dagger. A puncture wound is produced when a pointed thin bodied weapon is pushed into the body. Its depth is also greater than its diameter. A penetrating wound is produced when a bigger type of pointed weapon like teta is pushed into the body making a greater depth. When puncture or penetrating wound is such that it has an entry and an exit and a tract through the tissue it is called perforating wound. Legally puncture and penetrating wounds are also considered as stab wounds.

Firearm wounds ${ }^{2}$ - These wounds are produced by bullet or pellets fired from guns. Bullet usually causes perforation and pellets cause penetrating wounds. Firearm entry wounds are associated with burning, blackening, tattooing of the surrounding skin. Blast wounds $\mathbf{~}^{\mathbf{7 , 8}}$ are produced by explosion of bombs and are due to blast pressure wave (shock wave), blast winds, heat, splinters, shrapnels, surrounding small fragments propelled by blast winds.

To produce wounds the weapons are applied to the body or the body is applied to the weapon with various velocities. Different wounds have different characteristics and can easily be identified. Type and characteristics of wounds indicate the type of weapons. The weapons may be metallic, wooden, fibrous, stone like and even the parts of the body of the offender, viz, teeth, nails, feet, palm, hand fist, fingers, elbows and knees.

Burns ${ }^{14,15}$ are caused by flame, heated objects and scalds by hot liquids and vapours or gases. Bodily harm may also be caused by corrosives, electricity, insecticide, high dose of drugs.

Dangerous weapons and means ${ }^{1}$ : Following things and means have been designated as dangerous (BPC section Nos. 324, 326): Any instrument for shooting, stabbing, or cutting or any instrument used as weapon of offence and is likely to cause death or any means of fire or any heated substance, any poison, any substance deleterious to human body to inhale, swallow or to receive into blood or any animal for causing offence.

Complications of injuries: They are haemorrhage, shock, impairment of functions of vital organs, asphyxia, unconsciousness, infections, embolism etc.

Categorization 1,10 of hurt or injury: The following hurts or injuries are designated as grievous (BPC Section 320)

First- Emasculation. i.e. loss of male sexual ability.

Secondly- Permanent privation of the sight of either eye.

Thirdly- Permanent privation of hearing of either ear. 
A Barek, SMT Haque

Fourthly- Privation of any member (part of the body) or joint.

Fifthly- Destruction or permanent impairing of the powers of any member or joint.

Sixthly- Permanent disfiguration of the head or face.

Seventhly- Fracture or dislocation of a bone or tooth.

Eighthly- Any hurt which endangers life or which causes the sufferer to be, during the space of twenty days, in severe bodily pain or unable to follow his ordinary pursuits.

Any hurts other than the grievous ones are non grievous or simple hurts (BPC Section No 319)

Hurts that produce shock, asphyxia, or coma of the victim are considered endangering hurts. If no treatment is given, the victim may die. Hurts are necessarily fatal, meaning that no best treatment can save the victim from death.

Most hurts are caused by other persons directly or indirectly. They are the accused person. Some injuries may be self inflicted with a motive to accuse others for self interest or to avoid responsibilities or for self killing. The self inflicted wounds are usually caused by sharp cutting weapons. Those cut wounds are superficial, multiple, parallel and placed over the easily accessible sites of the body like wrist, neck, front of chest and abdomen.

Opinion regarding weapon or means: Types and characteristics of the wounds found over the body of the victim indicate the type of weapons or means, Viz, blunt, sharp, pointed, firearms, bombs, heat, corrosives etc.

Table: Penal Code section numbers (PCSN), hurt/ offences and punishments ${ }^{1}$

\begin{tabular}{lll}
\hline PCSN Hurt /offences & Punishments
\end{tabular}

323 Voluntarily causing simple hurt

Imprisonment $(\mathrm{S}=$ simple or $\mathrm{R}=$ rigorous $)$ extending up to 1 year or fine, extending up to $1000 /=$ Tk or both

324 Voluntarily causing simple hurt by dangerous weapon

Imprisonment ( $\mathrm{S}$ or $\mathrm{R}$ ) extending up to 3 years or fine or both

325 Voluntarily causing grievous hurt

Imprisonment ( $\mathrm{S}$ or $\mathrm{R}$ ) extending up to 7 years and fine.

326 Voluntarily causing grievous hurt by dangerous weapons or means

Imprisonment for life or imprisonment ( $\mathrm{S}$ or $\mathrm{R}$ ) extending up to 10 years and fine. 


\begin{tabular}{lll}
\hline PCSN & Hurt /offences & Punishments
\end{tabular}

326A Voluntarily causing grievous hurt to both eyes or head, face by corrosives (Vitriolage).

327 Voluntarily causing simple hurt to extort property or to constrain illegal act.

328 Causing simple hurt by poison with intend to commit and offence

329 Voluntarily causing grievous hurt to extort property or to constrain an illegal act

330 Voluntarily causing simple hurt to extort confession or to compel restoration of property.

331 Voluntarily causing grievous hurt to extort confession or to compel restoration of property.

332 Voluntarily causing simple hurt to deter public servant from his duty

333 Voluntarily causing grievous hurt to deter public servant from his duty

334 Voluntarily causing simple hurt on provocation

335 Voluntarily causing grievous hurt on provocation

336 Rash (act done without due consideration, reckless or hasty act) or negligent act endangering life or personal safety of others

337 Causing simple hurt by rash or negligent act endangering life or personal safety of others.

338 Causing grievous hurt by rash or negligent act endangering life or personal safety of others.

338A Causing grievous hurt by rash, driving or riding on public way to endanger life or personal safety of others.
Death sentence or life imprisonment and also fine.

Imprisonment ( $\mathrm{S}$ or $\mathrm{R}$ ) extending up to 10 years and fine.

Imprisonment ( $\mathrm{S}$ or $\mathrm{R}$ ) extending up to 10 years.

Life imprisonment or imprisonment ( $\mathrm{S}$ or $\mathrm{R}$ ) extending up to 10 years and fine.

Imprisonment ( $\mathrm{S}$ or $\mathrm{R}$ ) extending up to 7 years and fine.

Imprisonment ( $\mathrm{S}$ or $\mathrm{R}$ ) extending up to 10 years and fine.

Imprisonment ( $\mathrm{S}$ or $\mathrm{R}$ ) extending up to 3 years or fine or both

Imprisonment ( $\mathrm{S}$ or $\mathrm{R}$ ) extending up to 10 years and fine.

Imprisonment ( $\mathrm{S}$ or $\mathrm{R}$ ) extending up to 1 month or fine extending up to $\mathrm{Tk} 500 /=$ or both

Imprisonment ( $\mathrm{S}$ or $\mathrm{R}$ ) extending up to 4 years or fine extending up to $\mathrm{Tk} 2000 /=$ or both

Imprisonment ( $\mathrm{S}$ or $\mathrm{R}$ ) extending up to 3 months or fine extending up to $\mathrm{Tk} 200 /=$ or both

Imprisonment ( $\mathrm{S}$ or $\mathrm{R}$ ) extending up to 6 months or fine extending up to Tk $500 /=$ or both.

Imprisonment ( $\mathrm{S}$ or $\mathrm{R}$ ) extending up to 2 years or fine extending up to Tk $5000 /=$ or both

Imprisonment ( $\mathrm{S}$ or $\mathrm{R}$ ) extending up to 2 years or fine or both. 


\section{Conclusion}

Medical documentary evidences like medicolegal reports on hurts prepared by the medical practitioners are very important for the courts in making their legal judgments. The type of wounds and weapons, legal categories of hurts and their ages must be specifically noted in the injury reports: Medicolegal training and experiences strengthen the abilities of the medical expert witnesses. Punishment in term of fine fixed about 20 years ago now needs to be reconstituted at a higher level.

\section{References}

1. Ministry of law and justice, govt of People's Republic of Bangladesh, offences affecting the human body, In: The Penal Code, Dhaka, 1991: 86-90

2. Reddy KSN, Medicolegal aspects of wounds, In: The Essentials of Forensic Medicine and Toxicology, 24th Edn, Medical book company, Hyderabad, 2005: 241-63

3. Knight B, Wounding, In: Legal aspect of Medical Practice, $5^{\text {th }}$ Edn, Churchill livingstone, Newyork, 1997: 181-98.

4. Knight B, The pathology of wounds, In: Forensic Pathology, $1^{\text {st }}$ Edn, Edward Arnold, London, 1991: $123-150$

5. Knight B, The examination of wounds, In: Simpson's Forensic Medicine, 10th Edn, Edward Arnold, Kent 65-86.
6. Rabinowitch A, Medicolegal conclusions on the form of knife used based on the shape of stab wounds received, J Forensic Medicine, 1956; 6: 160-5.

7. Ryan JM, Warfare injuries In Baily \& Love's short practice of Surgery, 24th Edn, Hodder Arnold, Newyork, 2004: 291-301.

8. Islam AKMS, Barek A, Pattern of unnatural deaths in Barisal region, Bangladesh Medical Review, 11991; 17(1): 38-41.

9. Mant AK, Wounds and their interpretation, In: Taylor's Principles and Practice of Medical Jurisprudence, 13th Edn, Churchill livingstone, Edinburgh, 1984: 111-127.

10. Mallik cc, Legal procedure in India, In: A short Text Book of Medical Jurisprudence. $2^{\text {nd }}$ Edn, New Bookstall, Calcutta, 1984: 6-11.

11. Rich N M, Modern war wounds in the pathology of violent injury, $1^{\text {st }}$ Edn, Edward Arnold, London, 1978: 97-112.

12. Knight B, The dynamics of stab wounds, Forensic Sci, 1975; 6: 249-55.

13. Robertson J, Hudge PR, Histopathology of healing abrasions, Forensic Sci, 1972; I: 17-25

14. Bull JP, Burns, postgrad Med J 1963; 39: 717-25

15. Moritz A.R, Henriques F.C. Studies of thermal injury, the relative importance of time \& surface temperature in the causation of cutaneous burns. Am J Pathol 1947; 23: 695-704. 